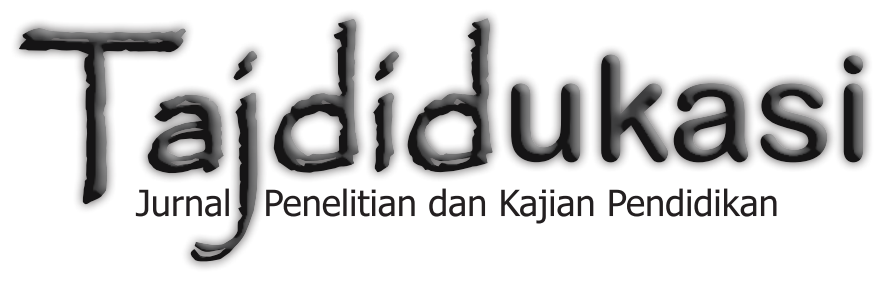




\section{Tajdidukasi}

Volume VIII, No. 1, Januari 2018

ISSN: 1979-6943

Tajdidukasi: Jurnal Penelitian dan Kajian Pendidikan merupakan jurnal Penelitian dan Kajian Pendidikan yang berisi Penelitian Tindakan Kelas (PTK) dan Penelitian Tindakan Sekolah (PTS) serta Kajian Pendidikan interdisipliner di Perguruan Tinggi yang diterbitkan Majelis Pendidikan Dasar dan Menengah Pimpinan Wilayah Muhammadiyah Daerah Istimewa Yogyakarta. Artikel hasil PTK dan PTS serta kajian pemikiran pendidikan ditulis oleh para Guru dan Kepala Sekolah serta Dosen dalam mengujicobakan metode dan strategi pembelajaran untuk meningkatkan kualitas pendidikan baik SD/MI, SMP/MTs dan SMA/MA/SMK serta Perguruan Tinggi. Artikel PTK dan PTS fokus pada mata pelajaran di sekolah/madrasah, seperti Ilmu Pengetahuan Alam (IPA), Imu Pengetahuan Sosial (IPS), Matematika, Fisika, Kimia, bahkan teknik, seperti Teknik Mesin, Elektro, Informatika dan lain sebagainya. Sementara itu, artikel Kajian Pendidikan merupakan penelitian interdisipliner dan multidisipliner yang dilakukan Dosen di Perguruan Tinggi terhadap khasanah keIslaman.

Tajdidukasi: Jurnal Penelitian dan Kajian Pendidikan adalah jurnal terbuka yang versi softfile-nya bisa dibaca dan diakses secara gratis, sementara versi print out/ hardcopy dapat diperoleh dengan menghubungi distributor di alamat serial tajdidukasi.ac.id. Sof-file keseluruhan artikel yang diterbitkan dapat diakses melalui Tajdidukasi Open Access Juornal di www.dikdasmenpwmdiy.or.id

\section{Pimpinan Editor \\ Suyadi, Universitas Ahmad Dahlan (UAD) Yogyakarta, Indonesia}

\section{Anggota Editor}

Arif Budi Raharjo, Universitas Muhammadiyah Yogyakarta (UMY), Indonesia

Achmad Muhammad, UIN Sunan Kalijaga Yogyakarta, Indonesia

Hendro Widodo, Universitas Ahmad Dahlan (UAD) Yogyakarta

Mundzirin Yusuf, UIN Sunan Kalijaga Yogyakarta, Indonesia

Sumedi, UIN Sunan Kalijaga Yogyakarta, Indonesia

Sukamto, Universitas Muhammadiyah Yogyakarta (UMY), Indonesia

Sumarsono, UIN Sunan Kalijaga Yogyakarta Indonesia

Sarjilah (Lembaga Penjaminan Mutu Pendidikan) Yogyakarta

Fathur Rahman, M.Si., Universitas Negeri Yogyakarta (UNY) Indonesia

\section{Editor Pelaksana}

Suryanto, Universitas Muhammadiyah Yogyakarta (UMY), Indonesia

Suyatno, Universitas Ahmad Dahlan (UAD) Yogyakarta

Farid Setiawan, Universitas Ahmad Dahlan (UAD) Yogyakarta

Alamat Redaksi:

Kantor Majelis Pendidikan Dasar dan Menengah Pimpinan

Wilayah Muhammadiyah D.I. Yogyakarta

Jl. Gedongkuning No. 130B Yogyakarta

Kode Pos : 55171

Telephone : (0274) 377078

Facsimile : (0274) 371718

Website : www.dikdasmenpwmdiy.or.id

E-Mail : tajdidukasi@dikdasmenpwmdiy.or.id 


\title{
MENINGKATKAN TEAMWORK SKILLS \\ MELALUI LAYANAN BIMBINGAN KLASIKAL \\ BERBASIS COOPERATIVE LEARNING
}

\author{
Nindiya Eka Safitri \\ SMK Muhammadiyah Wonosari \\ e-mail: nindiya26@gmail.com
}

\begin{abstract}
Abstrak
Pada umumnya laki-laki lebih mendominasi daripada perempuan. Akan tetapi, siswa laki-laki SMK Muhammadiyah Wonosari merupakan kelompok minoritas yang sepanjang proses pembelajaran cenderung lebih pasif meskipun sudah didorong guru untuk melakukan teamwork. Penelitian ini bertujuan untuk meningkatkan teamwork skills siswa melalui layanan bimbingan klasikal berbasis cooperative learning pada 34 siswa kelas X Jasa Boga SMK Muhammadiyah Wonosari. Metode penelitian yang digunakan adalah penelitian tindakan kelas dengan 2 (dua) siklus dimana setiap siklus terdiri dari 2 (dua) pertemuan. Teknik pengumpulan data menggunakan lembar observasi dan angket kemudian dianalisis dengan teknik statistik deskriptif berbasis komputer berbantuan Microsoft Excel 2013. Hasil penelitian pada pra tindakan menunjukkan bahwa siswa memiliki skor rata-rata 56,35 atau dalam kategori sedang. Hal ini menunjukkan bahwa siswa laki-laki dan sebagian siswa perempuan belum dapat berinteraksi, berkomunikasi dan menyelesaikan tugas kelompok dengan baik. Pada siklus I, skor rata-rata meningkat menjadi 65,32 atau kategori tinggi yang ditandai dengan perubahan pola komunikasi yang lebih intensif dan interaktif. Pada siklus II, skor rata-rata meningkat mencapai 68,08 atau berada dalam kategori tinggi. Hal ini menunjukkan bahwa siswa laki-laki dan perempuan mampu berinteraksi dan berkomunikasi secara aktif, bahkan berani mengungkapkan pendapat dan mempertahankan gagasannya secara kritis dan etis untuk menyelesaikan tugas kelompok.
\end{abstract}

Kata Kunci: teamwork, bimbingan dan konseling, bimbingan klasikal, cooperative learning

\section{A. PENDAhULUAN}

Pendidikan SMK yang berkembang saat ini adalah pendidikan berbasis Teaching Factory. Menurut Dirjen Pengembangan Sekolah Menengah Kejuruan Kemendikbud (2017), Teaching Factory yaitu pendidikan yang memadukan sepenuhnya antara belajar dan bekerja, tidak lagi memisahkan antara tempat penyampaian materi teori dan tempat materi produksi (praktek). Hal ini berarti siswa SMK nantinya akan mengalami pembelajaran yang didesain seperti dunia usaha dan dunia industryyang sebenarnya sehingga mereka harus dibekali dengan keterampilan kerja (employability skills). Menurut Robinson (2000: 1), employability skills are those basic skills necessary for getting, keeping, and doing well on a job. Yang artinya keterampilan bekerja (employability skills) adalah beberapa keterampilan dasar yang dibutuhkan untuk mendapatkan, menjaga dan melaksanakan sebuah pekerjaan dengan baik. Salah satu bagian dari employability 
skills yang penting untuk dikembangkan dalam diri siswa SMK adalah teamwork skills (Departemen of Education Australia, 2006). Dalam bekerja, lulusan SMK akan dihadapkan dengan berbagai macam karakteristik rekan kerja dan sangat besar kemungkinannya mereka akan masuk dalam sebuah teamwork. Sudjimat (2017:7) mengungkapkan bahwa "SMK graduates must possess include teamwork skills that include the sub dimensions: (a) the skills of working with others, and (b) the skill of participating in project and task". Sementara Simanungkalit \& Anna (2013:2) mengatakan bahwa kerjasama tim sangat diperlukan guna meningkatkan efisiensi kerja baik itu di perusahaan multinasional, swasta maupun pemerintahan. Jika perusahaan tidak memiliki kerjasama yang kuat antara divisi satu dengan divisi lainnya, maka hasil dari kerjanya tidak akan memuaskan dan tidak efisien (tepat waktu). Berdasarkan hasil survei National Association of College and Employee (NACE) Amerika Serikat terhadap 457 pemimpin tentang 20 parameter penting seorang juara, ternyata IP justru menjadi faktor penentu nomor 17, sementara kemampuan kerjasama (teamwork) menduduki peringkat 3 (Eko Widiyatno, 2012: 8). Teamwork skills pada siswa SMK ini tentunya sangat berpengaruh signifikan terhadap kesiapan kerja tanpa dibatasi dengan jenis kelamin maupun perbedaanperbedaan lain.

Faktanya, sebagian siswa SMK belum memiliki teamwork skills yang baik. Hasil studi pendahuluan melalui instrumen angket pada siswa kelas $\mathrm{X}$
SMK Muhammadiyah Wonosari pada tanggal 09 sampai dengan 19 Oktober 2017, menunjukkan hasil bahwa skor teamwork skills siswa mencapai angka 65,89 atau berada pada kategori sedang. Adapun indikator teamwork skills kategori sedang adalah masih adanya ketergantungan siswa terhadap ketua kelompok dalam mengerjakan tugas. Selanjutnya beberapa siswa masih belum bisa menerima pendapat orang lain atau ketika berpendapat tidak membiasakan berdiskusi terlebih dahulu dengan teman satu kelompok. Kelas yang memperoleh skor tertinggi adalah kelas X Akuntansi 1 dengan skor 70.15, sedangkan kelas yang memperoleh skor terendah adalah kelas X Jasa Boga dengan skor 56,36.

Selain itu, studi pendahuluan juga didukung oleh keterangan dari guru mata pelajaran dan wali kelas melalui kegiatan wawancara pada tanggal 23 sampai dengan 28 Oktober 2017, siswa kelas X Jasa Boga masih belum maksimal ketika melakukan kerja kelompok. Ketika kerja kelompok diperbolehkan menggunakan handphone, sebagian besar siswa masih terlihat asyik bermain handphone. Beberapa siswa memilih diam daripada berpendapat ataupun membantu pekerjaan kelompok. Dari 5 (lima) anggota kelompok, hanya 2 (dua) orang yang sungguh-sungguh menyelesaikan tugas dan sisanya hanya pasrah, sehingga terjadi dominasi kerja pada siswa yang rajin atau memiliki kemampuan yang lebih. Selain itu, siswa laki-laki SMK Muhammadiyah Wonosari merupakan 
kelompok minoritas yang sepanjang proses pembelajaran cenderung lebih pasif meskipun sudah didorong guru untuk melakukan teamwork.

Tuntutan pengembangan teamwork skills mengandung implikasi terkhusus kepada guru yang mengampu mata pelajaran teori maupun praktek kejuruan. Untuk dapat mewujudkan hal tersebut, guru mata pelajaran kejuruan tidak mungkin bisa bekerja sendirian, melainkan perlu bantuan dan dukungan dari pihak lain. Sebagaimana diungkapkan oleh Caraka \& Nindiya (2015: 55) bahwa bimbingan dan konseling sebagai bagian integral proses pendidikan memiliki kontribusi dalam penyiapan SDM bermutu, termasuk peningkatan teamwork skills. Dalam perspektif bimbingan dan konseling komprehensif, teamwork skills merupakan salah satu fokus pengembangan layanan peminatan dan perencanaan individual (individual planning services) dalam konsteks peningkatan kesiapan karir (bekerja). Dalam Lampiran Permendikbud RI 111/2014 disebutkan bahwa layanan peminatan dan perencanaan individual adalah bantuan kepada peserta didik agar mampu merumuskan dan melakukan aktivitas yang berkaitan dengan perencanaan masa depan berdasarkan pemahaman akan kelebihan dan kekurangan dirinya, serta pemahaman akan peluang dan kesempatan yang tersedia di lingkungannya. Ada banyak strategi pelaksanaan layanan perencanaan individual diantaranya adalah layanan bimbingan klasikal.

Layanan bimbingan klasikal sendiri merupakan layanan yang dilaksanakan dalam seting kelas, diberikan kepada semua peserta didik, dalam bentuk tatap muka terjadwal dan rutin setiap kelas/ perminggu (Lampiran Permendikbud RI 111/2014). Saat ini, pelaksanaan layanan bimbingan klasikal kebanyakan masih menggunakan model ceramah. Hal ini tentu kurang mendukung upaya peningkatan teamwork skills, sehingga perlu mengadopsi model lain. Hasil penelitian Yahya dkk (2017: 154) mengungkapkan bahwa "the implementation of a scientific approach contributes significantly to technical skills and employability skills of the students in Vocational High School Mechanical Engineering Package". Salah satu model pembelajaran saintifik yang sesuai adalah cooperative learning. Sedangkan cooperative learning sendiri adalah suatu model pembelajaran dimana siswa belajar dan bekerja dalam kelompokkelompok kecil secara kolaboratif yang anggotanya terdiri dari 2 sampai 5 orang, dengan struktur kelompoknya yang bersifat heterogen (Komalasari, 2011: 62). Melalui pembelajaran berbasis cooperative learning, siswa memiliki kesempatan besar untuk belajar mengembangkan keterampilan kerjasama tim secara intensif bersama rekan sekelas dalam kelompok yang berbeda.

Artikel ini akan menunjukkan dan membahas data hasil penelitian tindakan kelas tentang penerapan layanan bimbingan klasikal berbasis cooperative learning untuk meningkatkan teamwork skills. Bahasan yang diprioritaskan diantaranya adalah: 1) uraian 
peningkatan teamwork skills siswa pra tindakan hingga pasca tindakan beserta refleksi dan evaluasi; (2) implikasi dan saran bagi guru BK dalam upaya peningkatan teamwork skills; dan (3) urgensi hasil penelitian terhadap penyiapan lulusan dan peningkatan kualitas SMK berbasis Teaching Factory. Selanjutnya, hasil penelitian diharapkan memberikan kontribusi keilmuan dalam ranah pendidikan SMK sebagai stimulan penyiapan lulusan siap kerja.

\section{B. METODE PENELITIAN}

Subjek penelitan tindakan kelas ini adalah 34 siswa kelas X Jasa Boga terdiri dari 7 siswa laki-laki dan 27 siswa perempuan. Waktu penelitian adalah bulan Januari-Maret 2018. Adapun jenis penelitian yang digunakan peneliti yaitu Penelitian Tindakan Kelas (PTK). Menurut Suharsimi (2013: 3), Penelitian Tindakan Kelas merupakan suatu pencermatan terhadap kegiatan belajar berupa sebuah tindakan, yang sengaja dimunculkan dan terjadi dalam sebuah kelas secara bersama. Sedangkan menurut Suyadi (2013: 3), penelitian tindakan kelas merupakan pencermatan dalam bentuk tindakan terhadap kegiatan belajar yang sengaja dimunculkan dan terjadi dalam sebuah kelas secara bersamaan.

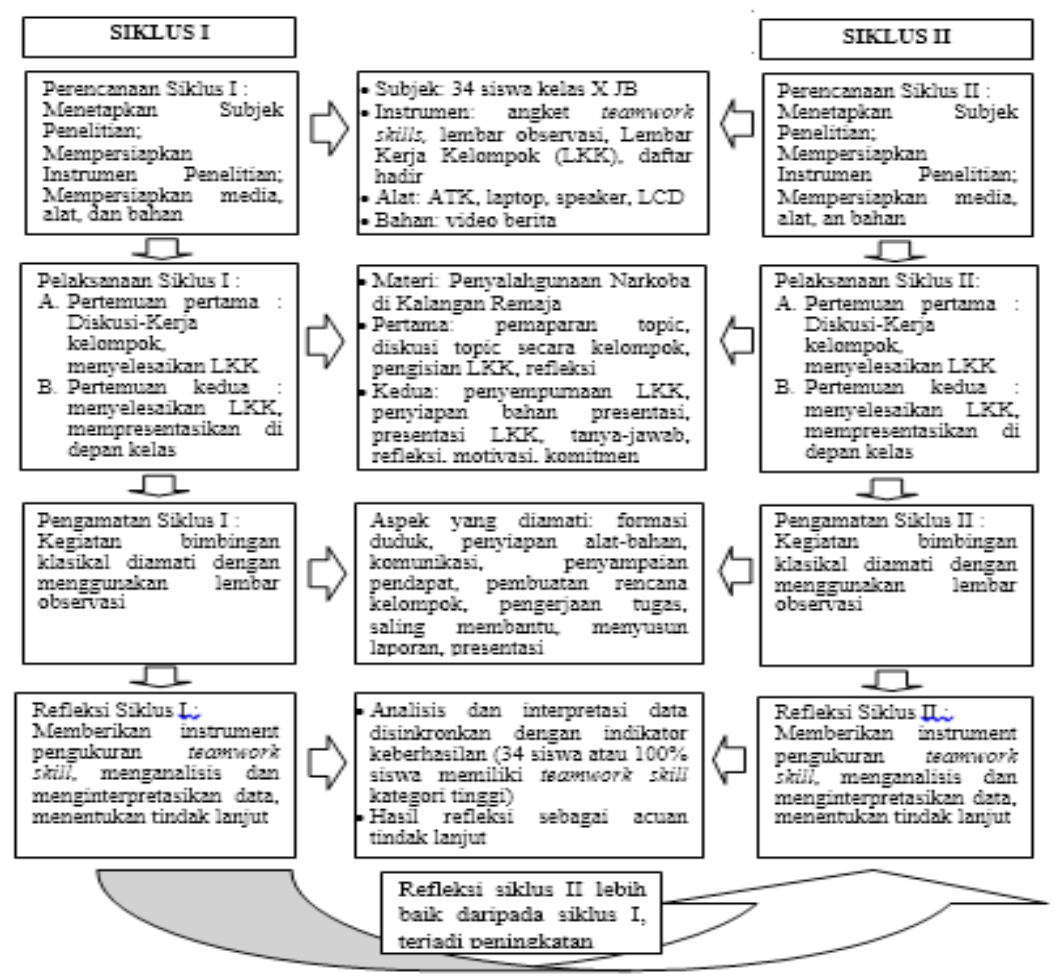

Gambar 1. Uraian Pelaksanaan Penelitian Tindakan Kelas 
Penelitian didesain dalam 2 (dua) siklus tindakan. Dalam satu siklus terdapat (4) empat tahap yaitu perencanaan, pelaksanaan, pengamatan dan refleksi (Suharsimi, 2013: 137). Tahap perencanaan, peneliti menjelaskan tentang apa, mengapa, kapan, dimana, oleh siapa, dan bagaimana tindakan tersebut dilakukan. Peneliti menentukan subjek layanan, materi layanan, tujuan layanan, RPL, instrumen pengumpulan data, bahan dan peralatan yang dibutuhkan selama pelaksanaan tindakan layanan bimbingan klasikal berbasis cooperative learning. Tahap pelaksanaan, peneliti memberikan perlakuan kepada siswa berupa kegiatan layanan bimbingan klasikal berbasis cooperative learning, mengacu pada langkahlangkah bimbingan klasikal yaitu mulai tahap pendahuluan, tahap inti dan tahap penutup. Tahap pengamatan, dilakukan kegiatan pengamatan terhadap kegiatan layanan bimbingan klasikal berbasis cooperative learning, dengan instrumen lembar observasi. Pengamatan dilakukan dalam waktu bersamaan dengan pelaksanaan tindakan. Terakhir, tahap refleksi, peneliti menganalisis apakah terjadi peningkatan teamwork skills setelah tindakan layanan bimbingan klasikal berbasis cooperative learning atau tidak. Refleksi menggunakan instrumen skala semantik diferensial. Apabila telah terjadi peningkatan, maka siklus tindakan dicukupkan. Sebaliknya, jika tidak terjadi peningkatan, maka dilanjutkan untuk siklus berikutnya. Demikian seterusnya hingga mencapai indikator keberhasilan penelitian yang telah ditentukan, yaitu terjadinya peningkatan teamwork skills siswa X Jasa Boga SMK Muhammadiyah Wonosari Tahun Pelajaran 2017/2018.

Pelaksanaan siklus I dilaksanakan mulai tanggal 29 Januari sampai dengan 10 Februari 2018. Terdiri atas 2 (dua) pertemuan, yaitu pertemuan pertama pada 01 Februari 2018 dan pertemuan kedua pada 08 Februari 2018. Sedangkan, siklus II dilaksanakan mulai tanggal 19 sampai dengan 28 Februari 2018. Sebagaimana siklus I, tindakan siklus II juga terdiri atas 2 (dua) pertemuan, yaitu pertemuan pertama pada 19 Februari 2018 dan pertemuan kedua pada 26 Februari 2018. Setiap pertemuan melalui 3 (tiga) tahapan, yaitu tahap pendahuluan, tahap inti dan tahap penutup sebagaimana tahapan layanan bimbingan klasikal (Kemendikbud, 2013: 12-13). Tempat pelaksanaan penelitian adalah SMK Muhammadiyah Wonosari, Jalan Alun-Alun Barat No.11, Wonosari, Gunungkidul.

Adapun pengumpulan data penelitian dilakukan dengan menggunakan instrument lembar observasi dan angket, dengan terlebih dahulu dilakukan uji validitas konstruk (construct validity) secara expert judgment dengan rumus product moment dan uji reliabilitas (rumus alpha cronbach). Kedua uji instrument ini dilakukan agar mendapatkan instrumen pengumpulan data yang tepat. Sementara itu, analisis data yang digunakan adalah teknik analisis statistik deskriptif berbasis komputer 
(Microsoft Excel 2013) untuk memperoleh data skor peningkatan teamwork skill dari pra tindakan hingga pasca tindakan.

\section{HASIL PENELITIAN DAN PEMBAHASAN}

Secara fitrah, laki-laki memiliki banyak kelebihan daripada perempuan sebagaimana dijelaskan dalam AlQur'an Surah An-Nisa ayat 34, bahwa kaum laki-laki itu adalah pemimpin bagi kaum wanita, karena Allah telah melebihkan sebahagian mereka (laki-laki) atas sebahagian yang lain (wanita) (Departemen Agama RI, 2004). Laki-laki itu mempunyai kelebihan atas wanita, di antaranya kekuatan badan, kekuatan akal, keteguhan, ketabahan dan kesabaran, sehingga memiliki kekuasaan dominan daripada perempuan (wanita).

Siswa laki-laki pada kelas X Jasa Boga SMK Muhammadiyah Wonosari merupakan kelompok minoritas yang sepanjang proses pembelajaran cenderung lebih pasif meskipun sudah didorong guru untuk melakukan teamwork dengan siswa perempuan. Data awal (pra tindakan) menunjukkan bahwa $100 \%$ atau 34 siswa kelas X Jasa Boga SMK Muhammadiyah Wonosari memiliki teamwork skills pada kategori sedang. Sedangkan skor rata-rata kelas adalah 56,35 yang juga termasuk kategori sedang. Hasil ini mengandung makna bahwa sebagian besar siswa belum dapat berinteraksi, berkomunikasi dan menyelesaikan tugas kelompok dengan baik atau masih kurang. Hasil penelitin ini tidak jauh beda dengan hasil penelitian Anjani dkk (2016: 94) yang menunjukkan bahwa keterampilan kerjasama dalam kelompok siswa kelas XI SMA Negeri 8 Surakarta masih tergolong kurang, sehingga perlu adanya desain pembelajaran inovatif yang dapat melatih keterampilan kerjasama dalam kelompok.

Data pra tindakan di atas juga dilengkapi dengan data hasil wawancara. Hasil wawancara dengan wali kelas dan guru yang mengampu di kelas tersebut mengindikasikan bahwa dalam tugas kelompok siswa laki-laki di kelas X Jasa Boga lebih pasif daripada siswa perempuan. Saat kerja kelompok, masih terdapat ketergantungan siswa terhadap ketua kelompok dalam mengerjakan tugas, sementara yang lainnya hanya ramai dan terima jadi. Selanjutnya, beberapa siswa masih belum bisa menerima pendapat orang lain. Dan ketika berpendapat tidak membiasakan berdiskusi terlebih dahulu dengan teman satu kelompok, sehingga ada kemungkinan bertentangan dengan anggota lainnya dalam satu kelompok. Data ini juga menguatkan data penelitian Anjani (2016: 95) dimana hasil observasi dan hasil wawancara guru dalam pembelajaran biologi pada materi sistem peredaran darah, bahwa pada proses pembelajaran guru jarang mengarahkan siswa dalam pembentukan kelompok. Pada saat guru membuat kelompok untuk berdiskusi atau mengerjakan tugas, guru mengalami kesulitan karena terdapat 
beberapa siswa yang pintar kurang mau berbagi sedangkan siswa yang merasa minder tidak mau bertanya sehingga sulit untuk memahami serta menyetujui tujuan kelompok dan memakan waktu lama dalam menyelesaikan tugas.

Tuntutan pengembangan teamwork skills tidak hanya menjadi tanggungjawab guru mata pelajaran kejuruan tetapi juga guru BK. Kemendikbud (2017) telah menerangkan bahwa guru BP/ BK dituntut untuk mengembangkan spiritual (KI-1) dan kompetensi sikap (KI-2), serta pengetahuan (KI-3) dan juga keterampilan (KI-4). Dalam konteks bimbingan dan konseling komprehensif, pengembangan teamwork skills termasuk dalam ruang lingkup layanan peminatan dan perencanaan individual (Permendikbud RI 11/2014). Hal ini dikuatkan oleh hasil penelitian Sukardi (2011: 176) yang menyatakan bahwa bimbingan tentang kejuruan (perencanaan karir) berdampak positif pada prestasi pembelajaran produktif, dimana dapat meningkatkan perilaku kerja pembelajaran praktik siswa yang menyangkut mental kerja, sikap kerja, keamanan kerja, motivasi kerja, disiplin kerja, dan kerja sama. Dengan demikian, guru BK dapat melakukan layanan bimbingan yang berorientasi pada peningkatan teamwork skills, diantaranya dengan setting layanan bimbingan klasikal.

Penelitian tindakan kelas ini diawali dengan pembagian kelompok. Siswa dibagi ke dalam 7 kelompok kecil dengan anggota kelompok antara 4 sampai 5 orang. Struktur kelompok bersifat hete- rogen dengan anggota campuran antara siswa laki-laki dan siswa perempuan. Terdapat materi pengantar yang diberikan peneliti untuk kemudian didiskusikan siswa melalui sistem penugasan kelompok (menggunakan Lembar Kerja Kelompok). Materi yang diberikan adalah "Sikap Positif Siswa Terhadap Penyalahgunaan Narkoba Di Kalangan Remaja”. Kelompok melakukan pembagian tugas lalu berdiskusi dalam periode waktu tertentu dan menuliskan hasil diskusi. Pada pertemuan kedua, siswa membuat laporan hasil kerja kelompok sesuai draft yang diberikan guru dan melakukan presentasi untuk mendapatkan feedback dari kelompok lainnya.

Pengumpulan data hasil penelitian dilakukan dengan kegiatan obervasi dan angket. Selama penelitian berlangsung, dilakukan pengamatan menggunakan lembar observasi untuk mengetahui tingkat teamwork skills siswa. Aspek yang diamati meliputi kesiapan, kemampuan berkomunikasi, kemampuan berpendapat, keterlibatan dalam diskusi dan penyelesaian tugas, perilaku membantu, keterlibatan dalam penyusunan laporan, serta keterlibatan dalam presentasi. Pada saat siklus I pertemuan pertama diperoleh skor rata-rata sebesar 17.5 atau berada pada kategori cukup. Kemudian pada saat siklus I pertemuan kedua diperoleh skor rata-rata sebesar 21.85 dan masih berada pada kategori cukup. Beberapa siswa terlihat sibuk sendiri selama proses kerja kelompok dengan bermain handphone, tetapi 
sebagian siswa sudah mulai mencatat hal-hal yang dirasa penting dan berusaha aktif dalam diskusi supaya tugas kelompok dapat terselesaikan dengan baik. Sementara itu, pada saat siklus II pertemuan pertama skor rata-rata meningkat menjadi 23.71 namun masih berada pada kategori cukup. Kemudian pada saat siklus II pertemuan kedua juga meningkat menjadi 25.57 dan sudah berada pada kategori baik. Siswa telah mencoba berdiskusi dengan teman kelompok, memberikan pendapat, membantu mencari sumber informasi melalui laptop, HP dan buku serta bekerjasama dalam menyusun laporan dan melakukan presentasi. Dalam prosesnya, siswa cukup tertib dan serius (sungguh-sungguh) dalam mengikuti layanan bimbingan klasikal.

Tabel 1. Data Hasil Observasi

\begin{tabular}{|l|c|c|c|c|c|}
\hline \multirow{2}{*}{ NO. } & \multirow{2}{*}{ KELOMPOK } & \multicolumn{4}{|c|}{ PERTEMUAN KE } \\
\cline { 3 - 6 } & 1 & $\mathbf{1}$ & $\mathbf{2}$ & $\mathbf{3}$ & $\mathbf{4}$ \\
\hline 1 & 2 & 20 & 22 & 25 \\
\hline 2 & 3 & 21 & 22 & 24 & 25 \\
\hline 3 & 4 & 23 & 22 & 26 & 29 \\
\hline 4 & 5 & 20 & 22 & 24 & 24 \\
\hline 5 & 6 & 21 & 23 & 25 & 26 \\
\hline 6 & 7 & 19 & 21 & 22 & 25 \\
\hline 7 & Jumlah Skor & $\mathbf{1 3 9}$ & $\mathbf{1 5 3}$ & $\mathbf{1 6 6}$ & $\mathbf{1 7 9}$ \\
\hline & Rata-Rata & $\mathbf{1 7 . 5}$ & $\mathbf{2 1 . 8 5 7 1 4}$ & $\mathbf{2 3 . 7 1 4 2 9}$ & $\mathbf{2 5 . 5 7 1 4 3}$ \\
\hline & & & & & \\
\hline
\end{tabular}

Hasil umum yang diperoleh setelah dilakukan melalui kegiatan observasi selama proses tindakan berlangsung adalah terjadinya peningkatan teamwork skills pada siswa kelas X Jasa Boga SMK Muhammadiyah Wonosari Tahun Ajaran 2017/2018 dari kategori cukup menjadi kategori baik. Penelitian Wulandari dkk (2015: 16) menyatakan bahwa peningkatan kualitas kerjasama dalam pembelajaran dapat dilihat dari jumlah mahasiswa yang aktif semakin banyak, perkuliahan tidak membosankan karena sebagian besar mahasiswa kelihatan antusias dalam belajar. Adapun indikator teamwork skills untuk kategori baik adalah siswa atusias mengikuti proses bimbingan klasikal, mendengarkan dengan baik, mencatat halhal penting, bersikap tertib dan sopan, aktif dalam berinteraksi, aktif dalam mengemukakan pendapat, menghormati pendapat siswa lain, bekerjasama dengan baik dan aktif membantu teman untuk menyelesaikan tugas kelompok.

Keberhasilan penelitian juga diukur dengan menggunakan angket teamwork skills. Hasil penelitian diperoleh dengan 
cara memahami dan menginterpretasikan perolehan skor (data) siswa pada saat sebelum beri tindakan dan setelah diberi tindakan siklus I maupun siklus II. Dimana sebelum diberikan tindakan, skor rata-rata teamwork skills siswa adalah 56,35 atau kategori sedang. Hasil ini mengandung arti sebagian besar siswa belum dapat berinteraksi, berkomunikasi dan menyelesaikan tugas kelompok dengan baik. Setelah diberi tindakan siklus I, skor rata-rata teamwork skills siswa menjadi 65.32 atau kategori tinggi. Artinya, kemampuan komunikasi antar siswa sudah lebih baik dengan pola komunikasi yang lebih intensif atau saling aktif berpendapat dan membantu teman. Selanjutnya dilakukan tindakan siklus I dan hasilnya menunjukkan peningkatan namun belum signifikan dan belum mencapai indikator ketercapaian penelitian sehingga dilakukan tindakan siklus II. setelah pemberian tindakan siklus II skor rata-rata teamwork skills siswa mengalami peningkatan hingga skor rata-rata mencapai 68.08 dan berada pada kategori tinggi. Dengan demikian, hipotesis penelitian dapat diterima.

Hasil penelitian di atas dapat dimaknai bahwa komunikasi dalam sebuah kelompok sangat menentukan tingkat teamwork skills. Sebuah tim yang baik memiliki anggota tim dengan keterampilan komunikasi efektif. Hal ini selaras dengan hasil penelitian Sugiarto (2017: 66) bahwa komunikasi adalah kunci dalam melakukan kerjasama tim sebagaimana terjadi pada tim TIMIKA Jakarta yang hingga saat ini masih beroperasional dengan baik. Indikator keberhasilan penelitian ini adanya adanya peningkatan teamwork skills ditandai peningkatan kemampuan siswa (anggota kelompok) dalam berinteraksi dan berkomunikasi secara aktif, bahkan berani mengungkapkan pendapat dan mempertahankan gagasannya secara kritis dan etis untuk menyelesaikan tugas kelompok. Keterampilan komunikasi dalam kelompok belajar saat ini akhirnya dapat berimbas pada keterampilan komunikasi dalam kelompok kerja ketika sudah bekerja. Simpulan ini memberikan penguatan terhadap penelitan sebelumnya yang mengungkapkan bahwa komunikasi yang diterapkan di tempat kerja berdampak positif bagi karyawan, yaitu perubahan sikap ke arah yang lebih baik dan juga hubungan antar karyawan serta karyawan dan pimpinan yang semakin membaik pula (Lawasi \& Boge, 2017: 54). Sementara itu, keterampilan dalam memahami peranan diri, mengungkapkan pendapat dan membantu rekan kerja juga menjadi faktor penting terwujudnya teamwork yang baik. Hal sebagaimana diungkapkan Setiyanti (2012: 65) bahwa untuk membangun kerjasama kelompok, ada beberapa hal yang perlu dilakukan antaralain, membangun rasa saling percaya, saling pengertian, keterbukaan, kejujuran dan keberanian, membangun komunikasi, realisasi diri, motivasi, saling ketergantungan dan lain sebagainya.

Adapun peningkatan skor teamwork 
skills siswa yang terjadi sepanjang proses penelitian dapat dilihat dalam tabel berikut.

\section{Tabel 2. Peningkatan Skor}

Teamwork Skills

\begin{tabular}{|l|l|l|}
\hline & \multicolumn{1}{|c|}{ Skor } & \multicolumn{1}{c|}{ Kategori } \\
\hline Pra Tindakan & 56.35 & Sedang \\
\hline Pasca Siklus I & 65.32 & Tinggi \\
\hline Pasca Siklus II & 68.08 & Tinggi \\
\hline
\end{tabular}

Secara umum, hasil penelitian tindakan kelas ini membuktikan bahwa layanan bimbingan klasikal berbasis cooperative learning dapat meningkatkan teamwork skills pada siswa kelas X Jasa Boga SMK Muhammadiyah Wonosari Tahun Ajaran 2017/2018. Hasil penelitian ini menguatkan hasil penelitian Nurnawati dkk (2014) yang menunjukkan bahwa pembelajaran cooperative learning tipe Think Pair Share yang diterapkan pada siswa kelas VIII MTs N Pecangaan di Bawu Jepara pokok bahasan alat optik dapat meningkatkan kerjasama dan hasil belajar siswa. Hasil penelitian ini juga relevan dengan teori yang dikemukakan oleh Isjoni (2014:27) bahwa cooperative learning dapat diterapkan untuk tujuan pengembangan keterampilan sosial, yaitu mengajarkan kepada peserta didik keterampilan kerjasama dan kolaborasi. Selain itu, hasil penelitian ini relevan dengan hasil penelitian Yahya dkk (2017: 154) yang menemukan bahwa "the implementation of a scientific approach contributes significantly to technical skills and employability skills of the students in Vocational High School Mechanical
Engineering Package" karena cooperative learning merupakan salah satu bentuk pembelajaran saintifik.

Selanjutnya, hasil penelitian ini merupakan bukti nyata bahwa guru BK memang memiliki kontribusi terhadap peningkatan teamwork skills siswa SMK. Teamwork skills menjadi bekal utama untuk mempersiapkan lulusan yang mampu bekerjasama di sekolah dan di dunia kerja nantinya. Hal ini selaras dengan sebuah laporan dari the Conference Board (2008) indicated that for four-year college graduates, prospective employers rated the importance of effective teamwork and collaboration second only to oral communication in contributing to job success. Artinya, kerjasama tim, kolaborasi dan komunikasi lisan yang efektif memiliki kontribusi penting terhadap kesuksesan dalam bekerja. Hasil ini juga menguatkan hasil penelitian Utaminingsih (2011) yang menyatakan bahwa salah satu jenis kompetensi yang diharapkan meningkatkan mutu lulusan adalah teamwork. Selanjutnya, penelitian Marpaung (2014: 33), Lakoy (2015: 981) dan Panggiki dkk (2017: 3018)) juga menyimpulkan bahwa kerjasama tim berpengaruh signifikan dan positif terhadap kinerja karyawan dalam sebuah perusahaan. Hal ini sesuai dengan arah pendidikan SMK dalam mencetak lulusan siap kerja yang nantinya menjadi karyawan dan bergabung dalam sebuah perusahaan/instansi kerja.

Kendati demikian, hasil penelitian ini mengandung implikasi bahwa da- 
lam pelaksanaan layanan bimbingan klasikal berbasis coorperative learning tidak dapat dilakukan dengan asal. Guru BK perlu memahami tentang prinsip pelaksanaan pembelajaran cooperative learning untuk menentukan desain yang tepat dan diintegrasikan ke dalam tahapan layanan bimbingan klasikal. Sebagaimana ditetapkan dalam Modul Pelatihan Layanan Bimbingan dan Konseling dari Kemendikbud (2013: 12-13), layanan bimbingan klasikal meliputi 3 tahapan yaitu tahap awal, tahap inti dan tahap penutup. Pembagian siswa ke dalam kelompok-kelompok kecil yang heterogen merupakan kegiatan tahap awal. Sebelum tahap inti, perlu dilakukan pendekatan, pengarahan dan kesepakatan tentang norma dan peran kelompok pada saat kegiatan berlangsung. Selanjutnya, guru BK memberikan topik untuk didiskusikan dan memberikan lembar kerja kelompok untuk diselesaikan dalam kurun waktu tertentu dengan didampingi oleh guru BK. Terakhir, masing-masing kelompok harus membuat laporan kerja kelompok dan mempresentasikan di depan kelas dengan disertai tanya-jawab antar kelompok. Seluruh proses kegiatan harus diamati dan diukur dengan instrument untuk mendapatkan data dan deskripsi hasil penelitian. Data kemudian dianalisis dengan teknik tepat dan tajam agar dapat menunjukkan terjadinya peningkatan teamwork skills siswa.

Implikasi umum lainnya adalah bahwa teamwork skills menjadi urgen dalam penyiapan lulusan siap kerja dimana san- gat besar kemungkinanya lulusan SMK akan masuk dalam sebuah teamwork dengan berbagai macam karakteristik rekan kerja. Teamwork skills tidak dapat terwujud seketika melainkan perlu proses panjang dan rumit. Untuk itu, upaya pengembangan teamwork skills tidak bisa dilakukan secara parsial melainkan secara kolaboratif antar stakeholder di lingkungan sekolah SMK. Aplikasi strategi peningkatan teamwork skills yang inovatif diharapkan dapat berdampak pada peningkatan kualitas teaching factory.

\section{KESIMPULAN}

Berdasarkan uraian data dan pembahasan hasil penelitian, maka ada beberapa kesimpulan yang dapat diambil, yaitu:

1. Terjadi peningkatan teamwork skills pada siswa kelas X JB SMK Muhammadiyah Wonosari Tahun Ajaran 2017/2018 setelah diberikan layanan bimbingan klasikal berbasis cooperative learning. Peningkatan terjadi pada kemampuan berinteraksi, berkomunikasi dan menyelesaikan tugas kelompok dengan baik. Hasil ini ditandai dengan interaksi dan komunikasi antar siswa yang aktif dengan perubahan pola komunikasi yang lebih intensif dan interaktif; serta keberanian mengungkapkan pendapat dan mempertahankan gagasannya dengan kritis dan etis untuk menyelesaikan tugas kelompok.

2. Layanan bimbingan klasikal berbasis cooperative learning merupakan salah satu model pendekatan/ 
pembelajaran saintifik yang dapat meningkatkan teamwork skills dapat ditingkatkan melalui pelaksanaan. Dimana kelas dibagi ke dalam kelompok kecil dengan struktur heterogen, kemudian guru memberikan satu topik diskusi dan memfasilitasi siswa untuk bekerjasama dalam kelompok dengan memberikan beban tugas berupa Laporan Kerja Kelompok yang harus diselesaikan secara kelompok.

\section{DAFTAR PUSTAKA}

Aleksander, P. J. E., Bell, B., Ployhart, R. E., Hollenbeck, J. R., \& Ilgen, D. R. (2005). An evaluation of generic teamwork skill training with action teams: Effects on cognitive and skill-based outcomes. Retrieved (01 September 2016) from Cornell University, School of Industrial and Labor Relations site. http:// digitalcommons.ilr.cornell.edu/ articles/46/

Anjani, Dewi, dkk. (2017). Profil Keteramplan Kerjasama Dalam Kelompok Siswa Kelas I SMA Negeri 8 Surakarta Pada Materi Sistem Peredaran Darah. Prosiding Seminar Nasional Pendidikan Sains II UKSW 2017 (p. 94-98)

Caraka, P. B., \& Nindiya, E. S. (2015, October). Implementasi Permendikbud RI Nomor 111 Tahun 2014 Dalam Pengembangan Layanan BK di Sekolah Menengah. In Prosiding Seminar Nasional Bimbingan dan Konseling (pp. 55-61).
Chayati, I., Purwanti, S., \& Nugraheni, M. (2016). Profil Teamwork Skill sebagai Gambaran Kemampuan Kompetitif Mahasiswa. Jurnal Pendidikan Teknologi dan Kejuruan, 22(1), (p. 46-54).

Conference Board. (2008). New Graduates' Workforce Readiness: The Mid-Market Perspective. (Research Report R-1413-08-RR), New York: The Conference Board, 2008.

Departemen Agama RI. (2004). AlQur'an dan Terjemahannya. Bandung: Jumanatul 'Ali-ART

Departmen of Education. (2006). Employability Skills. Victoria, Australia: Department of Education.

Eko Widiyatno. (2012). Indeks Prestasi Bukan Penentu Kesuksesan. Republika 17 Maret 2012, (p. 8)

Hidayat, Dede Rahmat. (2012). Penelitian Tindakan dalam Bimbingan dan Konseling. Jakarta: Indeks

Isjoni. (2011). Cooperative Learning. Bandung: Alfabeta

Kaswan. (2013). Leadership and Teamworking: Membangun Tim yang Efektif dan Berkinerja Tinggi melalui Kepemimpinan. Bandung: Alfabeta

Kemendikbud. (2017). Teaching Factory. Materi Powerpoint, dipresentasikan dalam Workshop Pengembangan Teaching Factory SMK Muhammadiyah Wonosari pada 
Nindiya Eka Safitri - Meningkatkan Teamwork Skills Melalui Layanan Bimbingan Klasikal Berbasis ....

\section{3-14 Oktober 2017.}

Kemendikbud. (2013). Modul Pelatihan

Peningkatan Kompetensi Guru Bimbingan dan Konseling/Konselor. Jakarta: Kemendikbud.

Kemendikbud. (2016). Panduan Operasional Penyelenggaraan Bimbingan dan Konseling Sekolah Menengah Kejuruan (SMK). Jakarta: Dirjen GTK, Kemendikbud.

Lakoy, Amanda Carolina. (2015). Pengaruh Komunikasi, Kerjasama Kelomok, dan Kreativitas Terhdap Kinerja Karyawan Pada Hotel Aryaduta Manado. Jurnal EMBA, Vol. 3, No. 3, September 2015 (p. 981-991).

Lawasi, Eva Lawasi \& Bode Triatmanto. (2017). Pengaruh Komunikasi, Motivasi dan Kerjasama Tim Terhdap Peningkatan Kinerja Karyawan. Jurnal Manajemen dan Kewirausahaan, Vol. 5, No. 1, 2017 (p. 47-57)

Marpaung, Marudut. (2014). Pengaruh Kepemimpinan dan Teamwork Terhadap Kinerja Karyawan di Koperasi Sekjen Kemendikbud Senayan Jakarta. Jurnal Ilmiah WIDYA, Volume 2, Nomor 1, Maret-April 2014 (p. 33-40)

Nurnawati, Enis, dkk. (2012). Peningkatan Kerjasama Siswa SMP Melalui Penerapan Pembelajaran Kooperatif Pendekatan Think Pair Share. Unnes Physics Education Journal, UPEJ (1) (2012) (p. 1-7)
Paizaluddin \& Ermalinda. (2014). Penelitian Tindakan Kelas (Classroom Action Research). Bandung: Alfabeta.

Panggiki, Agatha Cristine, dkk. (2017). Pengaruh Kompensai, Kerjasam Tim dan Kepuasan Kerja Terhdap Kinerja Karyawan Pada Ajb Bumiputera 1912 Cabang Sam Ratulangi. Jurnal EMBA, Vol. 5, No. 2, September 2017 (p. 3018-3027)

Peraturan Menteri Pendidikan dan Kebudayaan Republik Indonesia Nomo 111 Tahun 2014 tentang Bimbingan dan Konseling Pada Pendidikan Dasar dan Menengah.

Purwanto, S. 2008. Paket Mentor Memimpin Tim. Jakarta: Esensi.

Robinson, Jacquelyn P. (2000). What Are Employability Skills?. Albama Cooperative Extension System, Vol. 1, Issue 3, September, 2000 (p. 1-3)

Rosita, Ita \& Leonard. (2013). Meningkatan Kerjasama Siswa Melalui Pembelajaran Kooperatif Tipe Think Pair Share. Jurnal Formatif Vol. 3, No. 1, Universitas Indraprasta PGRI

Sanjaya, Wina. (2009). Strategi Pembelajaran Berorientasi Standar Proses Pendidikan. Jakarta: Kencana

Setiyanti, Sri Wiranyi. (2012). Jurnal STIE Semarang, Vol. 4, No. 3, Edisi Oktober 2012 (p. 59-65)

Simanungkalit, D. R. (2013). Analisis Hubungan Kerjasama Tim Untuk Meningkatkan Efisiensi Kerja Pada 
PT Mitha Samudera Wijaya Medan. Jurnal Media Informasi Manajemen, Vol.1, No. 4.

Sudjimat, D.A. (2017). Employability skills of vocational high school graduate needed by industry in century XXI. In AIP Conference Proceedings (Vol. 1887, No. 1, p. 020046). AIP Publishing.

Sugiarto, Tommy. (2017). Evaluasi Proses Kerjasama Tim Dalam Bisnis Timika. PERFORMA: Jurnal Manajemen dan Start-Up Bisnis, Volume 2, Nomor 1, April 2017 (p. 62-67)

Suharsimi Arikunto. (2013). Prosedur Penelitian: Suatu Pendekatan Praktik. Jakarta: Rineka Cipta.

Sukardi, Th. (2011). Peranan Bimbingan Kejuruan Terhadap Pembentukan Karakter Kerja Siswa di Jurusan Mesin SMK N 2 Wonosari. Jurnal Cakrawala Pendidikan, Mei 2011, Th. Sukardi, Edisi Khusus Dies Natalis UNY (p. 167-177)

Suyadi. (2013). Panduan Guru Profesional Penelitian Tindakan Kelas (PTK) dan Penelitian Tindakan Sekolah (PTS), Yogyakarta: Andi Ofset

Tim Maxi Plus. (2007).Teamwork Games: Cara Menyenangkan Membangun Tim Impian. Bandung: Progessio.
Trianto. (2011). Mendesain Model Pembelajaran Inovatif-Progresif. Jakarta: Kencana

Utaminingsih, Sri. (2011) Model Manajemen Pengembangan Soft Skills SMK Program Keahlian Pariwisata. Jurnal Ekplanasi Volume 6 Nomor 2, Edisi September 2011 (p. 169183)

Warsihan. (2005). Modul Pelatihan Budaya Kerja dan Kerjasama Tim. Jakarta: Pusat Teknologi Informasik dan Komunikasi Pendidikan, Kemendikbud.

Wulandari, Bekti, dkk. (2015). Peningkatan Kemampuan dalam Tim Melalui Pembelajaran Berbasis Lesson Study. Journal Electronics and Vocational Education (ELINVO), Volume 1, Nomor 1, November 2015 (p. 9-16)

Yahya, Muhammad, et.al. (2017) Technical Skills and Employability Skills of Vocational High School Student in Indonesia. Journal of Scientific Research and Studies, Vol. 4(6), Juni 2017 (p. 148-155) 